THIS DOCUMENT MUST NOT BE LEFT UNATTENDED OR WHERE AN UNAUTHORIZED PERSON MAY HAVE ACCESS GUARDED AREA. WHILEE, IT MUST BE STORED IN AN APPROVED LOCKED REPOSITORY WITHIN AN APPROVED CLASSIFIED FILES, IT IS YOUR RESPOSSESSION AND UNTIL YOU HAVE OETAINED A SIGNED RECEIRT FROM THIS PRONECT AND FROM YOUR RESPONSIBILITY TO KEEP IT AND ITS CONTENTS WITHIN THE LIMITS OF OF RESIDENCE IS PROM ANY UNAUTHORIZED PERSON. ITS TRANSMITTAL TO, AND STORAGE AT YOUR PLACE OQTAIN THEM FROM THE RELATED ISSUINOT TO BE DUPLICATED. IF ADDITIONAL. COPIEB ARE REQUIAED, TO SIGN IN THE SPACE PROVIDED GELOW. FILE. ALL PERSONS READING THIS DOCUMENT ARE REQUEBTED

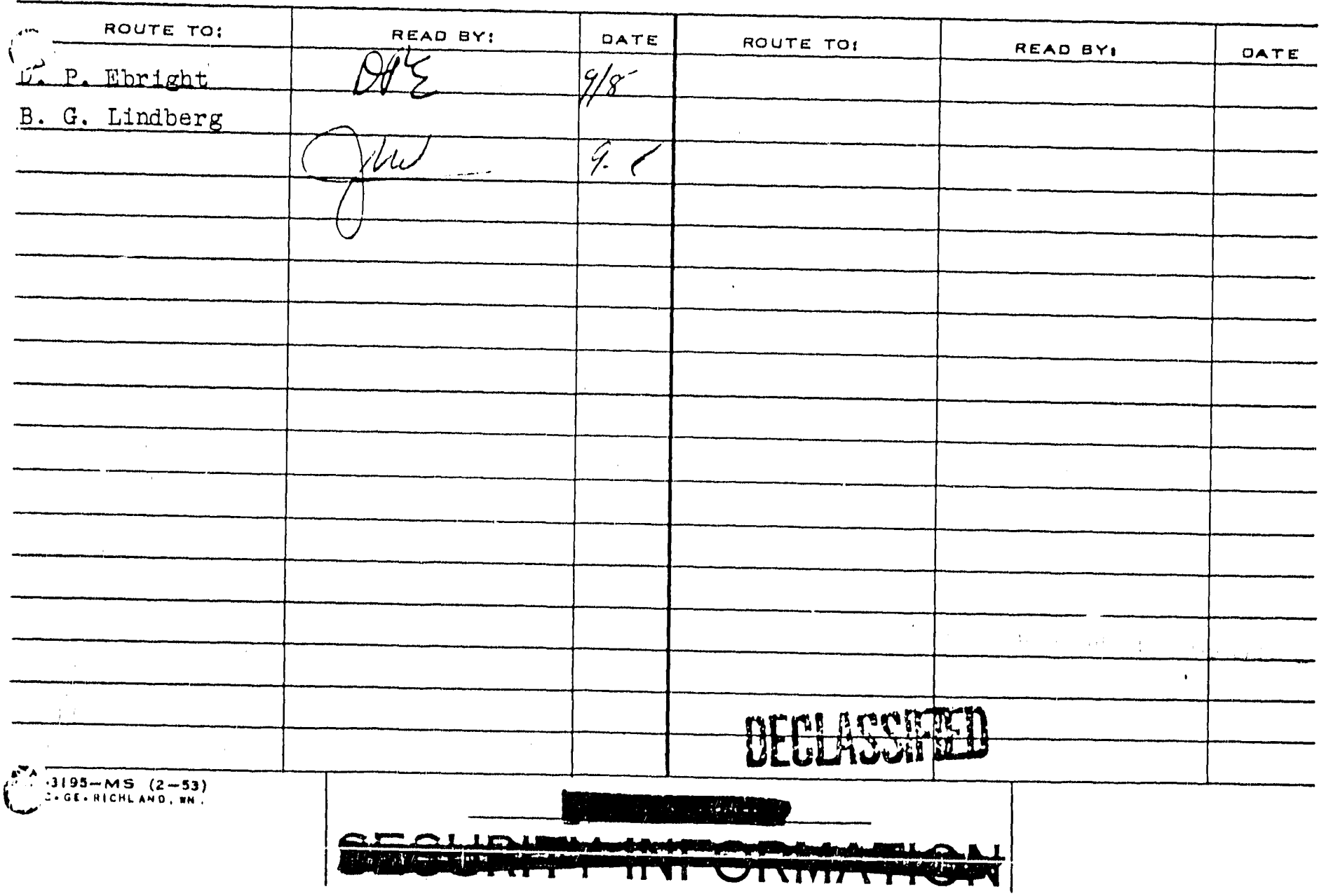



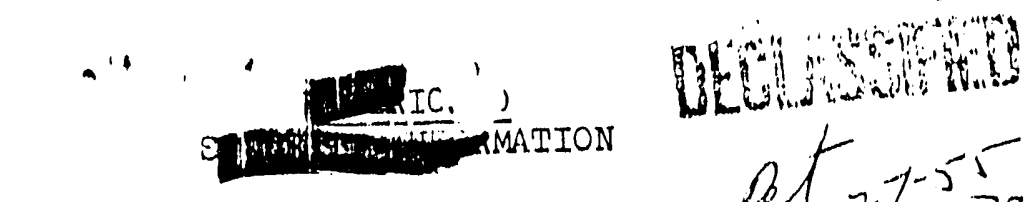

M:HW-29230

C.

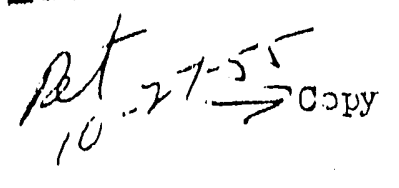

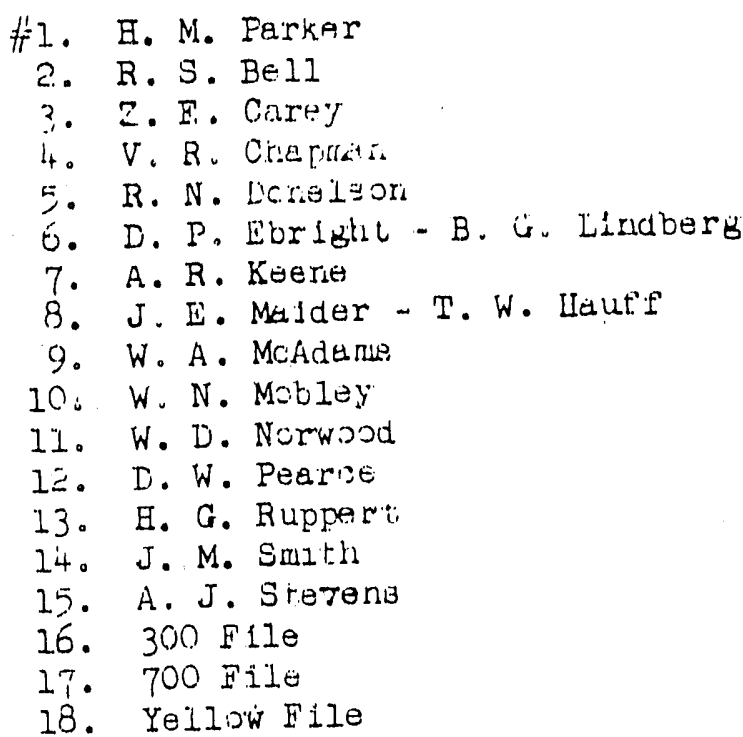

This material contains information affecting the nat1onal derense of the

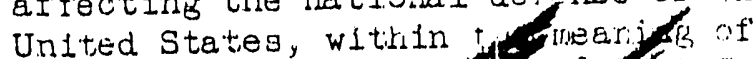
the esplonege laws. Secs. 793 and 79 revelation of ch in crancer to by law.

This docurrent consiats of 4 parea, Classivication Canculled (Cranga to

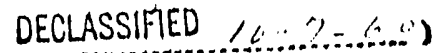
By Authowity of HAPO Speciallst Cinesiflcation.Declassiflcation No. 6 ot 18 copies, Seriog A Auguat 25, 1953

To E11日:

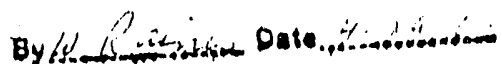

\section{RADIOLOGICAL SCIENCES DEPARTMENT INVESTIGATION RADIATION INCIDENT, CLASS I, NO. 299}

Nature of Incident

Deposition of large fragments of radioactive materlal in the Redox area during the period August 7 to $18,1953$.

\section{Description of Incident}

Routine surveys performed by Radiation Monttoring (Separations) on August 14 , 1953 and by Regional Survey (Radiologlcal Solences) on Auguat 17, 1953 revealed the presence of large fragments or chunks of radivective material on the ground ourrounding and extending generally in a direction southeast of the Redox stack as shown in the attached sketch.

Laboratory analyses Indicated, that, the bulk of the material was easentially ammonium nitrate and that the radioectivity was due primarily to ruthenfum though oome rare earthe were deteoted. Some of the fragments were observed to be several inches in width and length, up to $\frac{1}{2}$ to $3 / 4$ of an inch thick, and gray to white in color. Some of them were observed to be concave - convex if they mave been formed on a circular base such as the lnside of a plpe or the stack. The alze and general activity level of the particles during this incident far exceeded tnet of elther of the two previously reported incldents. (1) A max.1mum exposure rate of $15 \mathrm{rep} / \mathrm{hr}$ including $300 \mathrm{mr} / \mathrm{hr}$ uncorrected for source alze, wes obeerved on one fragment.

(I) $\mathrm{HW}-27447$, $\mathrm{BW}-27431$ 
Discussion of Inc1dent

The exact day on which those large farticles were tirst releaked from the atark 13 not known though it 10 bitleves that they wara rat presenti prior 20

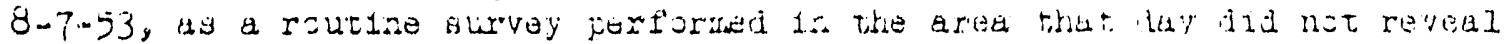

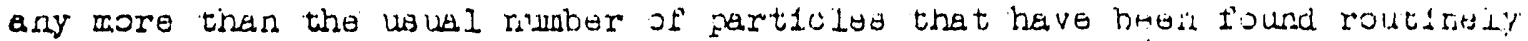
alnce the diacovery of thls condition in Aplil, 1952. (Routine weskly durveys of f1lter frames positioned arouid the 3 tack hare lridcated that thure has been a more or lose constant ratie of depultion of approxinateli ore particlo/aq te/ month in the east gection of the Redix ara alnce Afril, Ijse.) As these large

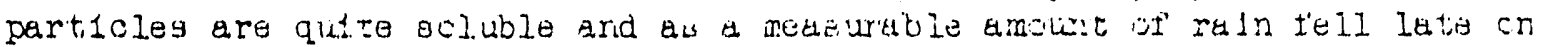

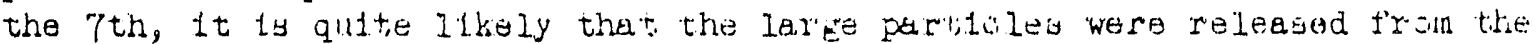
stack becween tine 8 tin and $14 \mathrm{th}$ of Augut, 155:. Adaltional larige farticles were observed comlng out of tile Redox gtack en the ibth of August.

No unusual operation 1.8 knowr to have been in progresa in the proceus bullding at the time the large partiales were observed coming from tile stack on the i8th. It is theorlzed that these large particles and the majority of the amall ones are the reault of crystal formation by reaction between the $\mathrm{NH}_{3}$ lon relaused In the jacket ramoval atep and the oxides of nitrogen released in the disuolving step. It 1 s believed that this reaction might take place in the meln atack during mixing of' of'f-geses from two disoolvere which ney be operating concurrently at the two procese ateps mentioned. It is quite posilble that the reaction might, occur even if the two operations were nut performed simultaneously as It 1 is quite probable that any liquid in the off-gas lines or on the stack 1 iner Ig a.lwaye saturated with one or the other of the components and the ultimate presence of the eecond comporient will likely rasuit in the formation of aid arnonium nitrate cryotal.

The exact source of the ruthenlum which ultimately coatg the crystals "of amonium nitrate $1 \mathrm{~s}$ not at present quite go well known, though it quite likely enters the stack by the vessel vent system off-gas I1nes. The ruthenium ocrubber, H-5 tank, may also occasionally pase ruthenlum through to the stack.

Discussion of Exposure

Though there kes been no reported extended exposure of personnel to this activity, It cannot be unequivocally stated that no inhalation of this contamination by personnel occurred. Alr eamples taken esst of the stack on the l8th revealed a particle concentration of approximately 140 particles/ou meter of alr. Normal concentrations in this vicinity are expected to run considerably loge then one particle/cu meter of air.

The number and average activity of particles that oan be associated with this Incident and that were found in the vicinity of the 200 .W area southwest fence Ine (adjecent to a major construction area) 1ridicate that there 1o littie posalbility of their having contributed any algniflcant exposure to any personnel working in this aroa.

Cause of Inc1dent

1. Lack of adequate facilities to removes ruthenilun from the bullding exhaust uystein.

2. Lack of adequate facilitios to inhlbit the formation and/or release of porticulate material in the bullding exhaust sytom. 


\section{Comment, on the Inoldent}

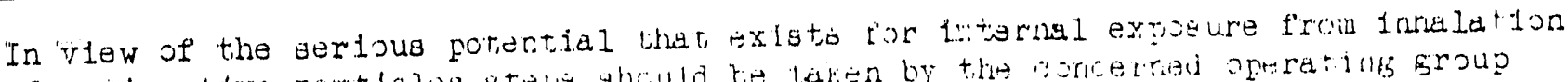

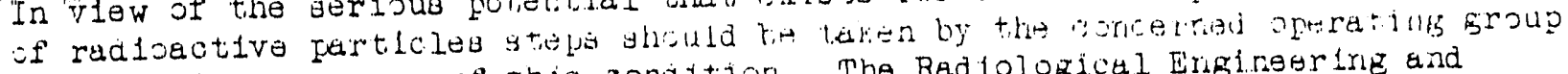
to prevent recurrence of this sondition. The Radiological Erigingering and Elophysica groups of the Radiological Sulenter Departinert way bo consulted fior aselstance on the problem.

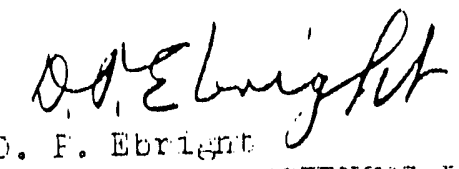

[. F. Euritirt

RADIOLOGICAL SCIENCHS LEPARTMEINT

DPE :bc 


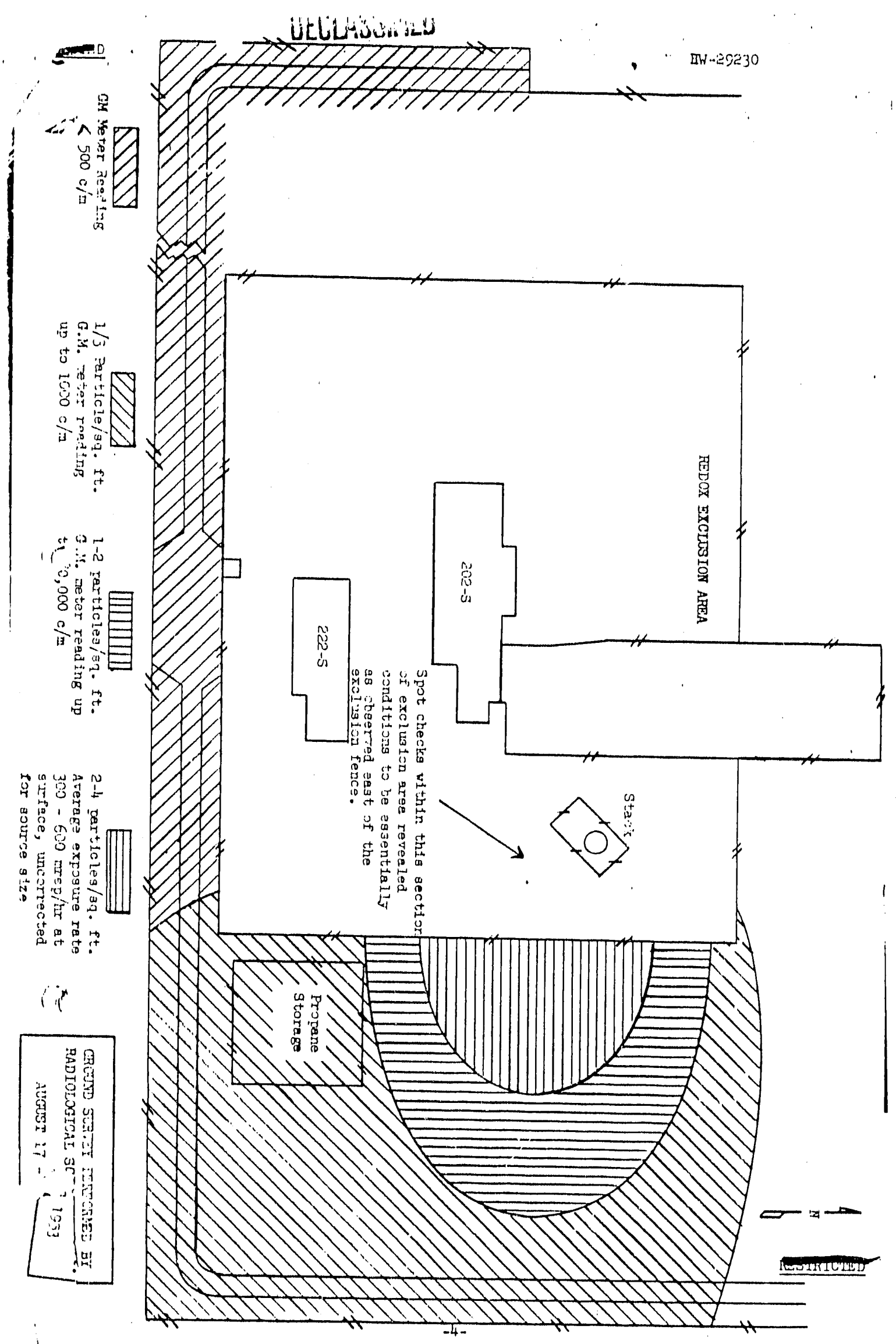



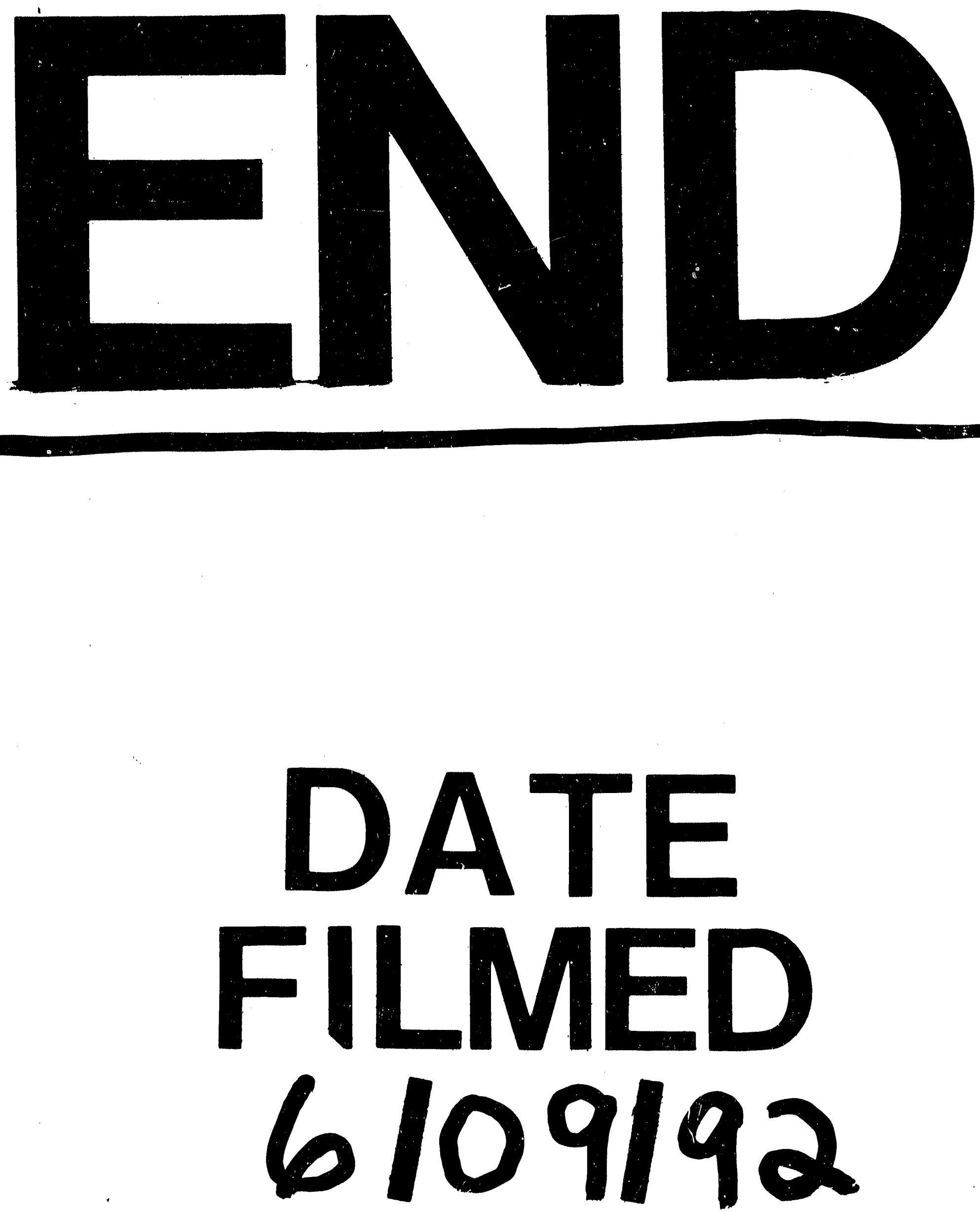


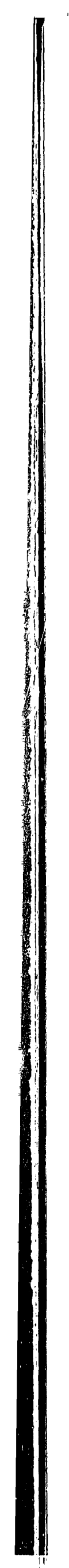

